\title{
ETNOBOTANI MASYARAKAT SAMAWA PULAU SUMBAWA
}

\author{
MULYATI RAHAYU, HIMMAH RUSTIAMI \\ Bidang Botani, Pusat Penelitian Biologi LIPI, Cibinong Science Center, Cibinong Bogor
}

\section{A B S T R ACT}

We have conducted ethnobotany research in Batudulang Village of Batulanteh Subdistrict, Sumbawa Island, West Nusa Tenggara. This study was a direct observation method and data were collected by interview. This study aimed to determine the interaction of local community and its environment and to determine the local knowledge of useful plants. We recorded the people of Samawa utilized 147 plants, 39 were edible plants, 74 were medicinal including cosmetics plants, 12 were sources for building materials and handicrafts, and the rest of 22 were honeybee feed plants, firewood, and ritual plants. This study also revealed that the Samawa community has local wisdom in the importance of sustainable used of the forest as a habitat for wild honeybees.

KEY WORDS: Batudulang, ethnobotany, Samawa, useful plants

\section{PENDAHULUAN}

Indonesia merupakan negara dengan tingkat keragaman yang tinggi; baik keragaman hayati, maupun keragaman tradisi. Dari keragaman tersebut memunculkan pengetahuan lokal dalam interaksinya dengan lingkungan serta pemanfaatan tumbuhan untuk kebutuhan sehari-hari. Pengetahuan lokal ini antara satu daerah dengan daerah lainnya berbeda, tergantung pada tradisi dan keragaman hayati yang ada di daerah tersebut.

Masyarakat Samawa merupakan salah satu etnis asli yang mendiami pulau Sumbawa, Propinsi Nusa Tenggara Barat. Masyarakat Samawa sangat menghargai lingkungan dan kekayaan jenis tumbuhan yang ada disekitarnya serta menempatkannya dalam kedudukan yang penting terkait dalam kehidupan sehari-hari. Berdasarkan pustaka yang ditelusuri, belum banyak penelitian pengungkapan pengetahuan lokal dan pemahaman masyarakat Samawa terhadap lingkungan dan pemanfaatan tumbuhan yang ada disekitarnya sebagai suatu upaya untuk mempertahankan hidup dan mengembangkan keturunan.

Peneliti dari Pusat Penelitian Biologi pada tahun 2016 melakukan perjalanan eksplorasi ke pulau Sumbawa sebagai salah satu kegiatan penelitian DIPA Keanekaragaman tumbuhan dan potensinya di kawasan Kepulauan Sunda Kecil. Rench (1930) dan Kostermans (1963) adalah dua rujukan yang paling sering digunakan untuk keragaman hayati tumbuhan Pulau Sumbawa, demikian pula informasi kajian etnobotaninya. Kegiatan eksplorasi difokuskan dikawasan hutan Batulanteh, Kabupaten Sumbawa dengan mengumpulkan spesimen herbarium tumbuhan serta menggali informasi potensi tumbuhan yang dimanfaatkan oleh masyarakat lokal di lokasi penelitian. Potensi yang digali antara lain adalah pemanfatan tumbuhan untuk obat-obatan, bahan pangan dan bahan bangunan. Spesimen herbarium yang dikoleksi disimpan di Herbarium Bogoriense, Pusat Penelitian Biologi (LIPI). Tujuan kegiatan etnobotani ini terutama untuk mengungkapkan lebih jauh tentang pemahaman masyarakat Samawa terhadap lingkungan dan pengetahuan tradisional pemanfaatan tumbuhan oleh masyarakat lokal.

\section{ME T O DE}

Penelitian dilakukan di Desa Batudulang, Kecamatan Batulanteh-Kabupaten Sumbawa, Nusa Tenggara Barat. Desa ini terletak di kawasan hutan pegunungan Batulanteh (Gambar 1), pada titik koordinat S $08^{\circ} 36^{\prime} 25,5^{\prime \prime}$, E $117^{\circ} 16^{\prime}$ 20,5". Kawasan ini merupakan salah satu kawasan konservasi di Kabupaten Sumbawa Besar, yang dikelola oleh Kesatuan Pengelolaan Hutan Produksi (KPHP) yang berperan penting sebagai hulu Daerah Aliran Sungai (DAS) Sumbawa sebagai penyangga dan penyuplai air kota Sumbawa. Kawasan ini juga merupakan habitat lebah madu penghasil utama madu hutan.

Pengumpulan data dilakukan dengan menggunakan metode Walk in the Wood (Cunningham, 2001; Hoang et al., 2008; Rahayu et al., 2016) yaitu wawancara dan pengamatan langsung di lapangan. Responden terpilih (key person) yang digunakan sebanyak 30 orang adalah anggota masyarakat yang mampu memberikan informasi akurat, memiliki pengetahuan yang baik tentang lingkungan dan keragaman jenis tumbuhan berguna. Kriteria pemilihan informan antara lain penduduk asli dan telah bertempat tinggal di desa Batudulang minimal 20 tahun, berumur lebih dari 35 tahun dan mengenal atau memanfaatkan jenis-jenis tumbuhan berguna. Alasan pemilihan informan dengan kriteria tersebut di atas dimaksudkan agar data yang diperoleh akurat karena informan tersebut mengetahui perubahan yang terjadi di kawasan hutan Batulanteh, khususnya Batudulang.

\section{HASIL DAN PEMBAHASAN}

Di masa lalu masyarakat Samawa membentuk perkampungan atau pemukiman penduduk di daerah pegunungan dan rumah berpencar-pencar. Namun saat ini pemukiman penduduk terkonsentrasi di dekat sumber mata air dan aksesnya mudah. Bentuk satuan lingkungan yang dikenal oleh masyarakat Samawa Batudulang ada 4, masing-masing dengan sebutan nama lokal yaitu; pemukiman penduduk kapung, hutan olat kapung atau dasa, rawu/ladang, dan keban/ kebun. 


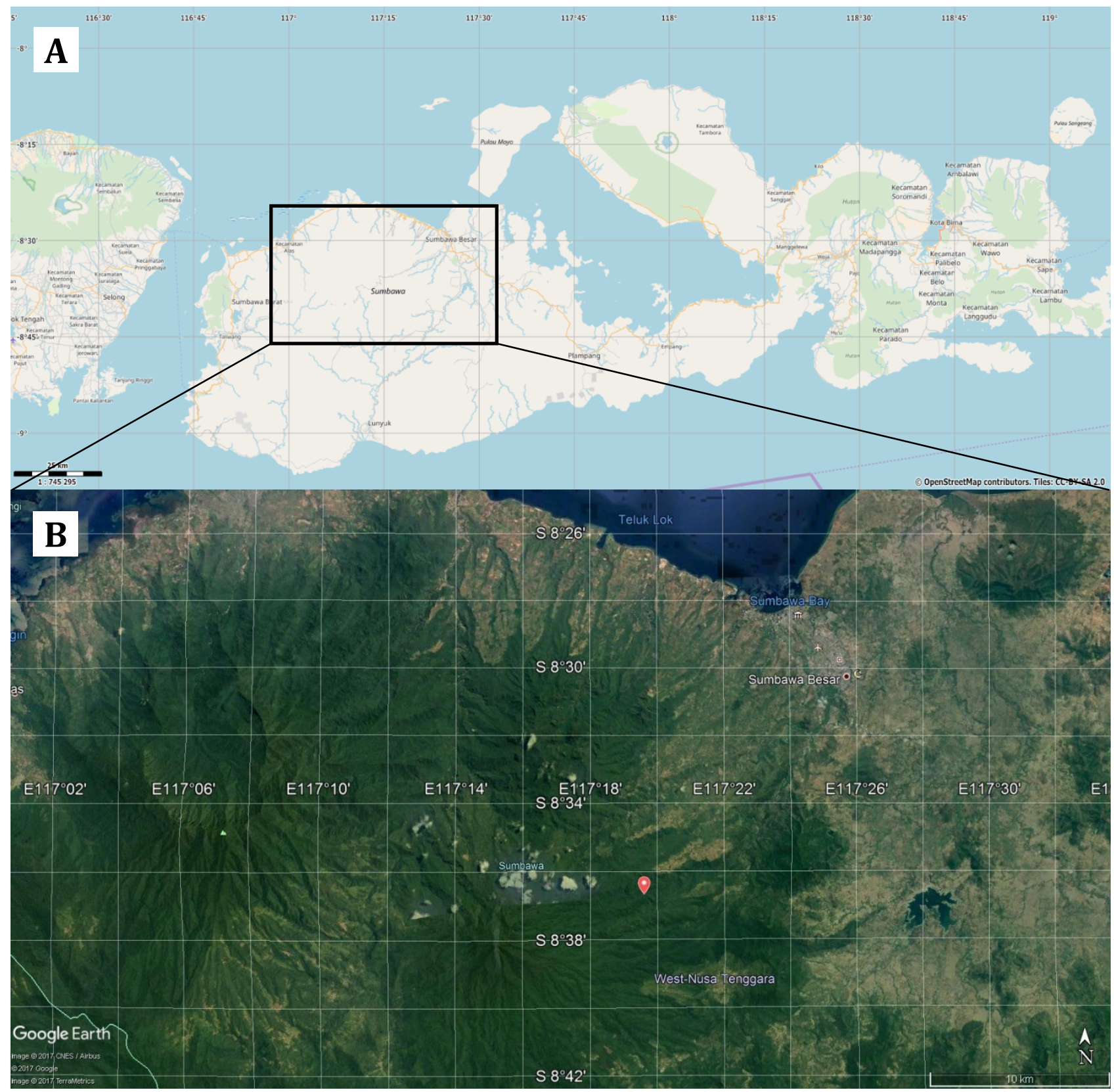

Gambar 1. Peta Pulau Sumbawa (A) dengan inset lokasi penelitian di Desa Batudulang (tanda pin merah), Kecamatan Batulanteh, Kabupaten Sumbawa, Nusa Tenggara Barat (B).

Bentuk bangunan asli sebagai tempat tinggal masyarakat Samawa berupa rumah panggung kayu yang disebut bale panggung, berdinding anyaman bambu dan beratapkan santek, yang terbuat dari seruas bambu treng atau ae yang dibelah dua kemudian dibelah lagi bagian tengahnya dan disusun seperti atap sirap (Gambar 2). Bentuk bangunan rumah panggung merupakan tipe asli rumah bangsa besar Austronesia (Fox, 1993; Telle, 2007). Bentuk bangunan rumah asli sudah tidak dijumpai lagi di desa Batudulang, dan digantikan dengan bentuk rumah panggung dari batu dan semen. Namun, atap santek masih digunakan untuk atap alang atau lumbung padi. Fenomena ini dapat ditafsirkan bahwa pade/padi (Oryza sativa) memiliki nilai penting bagi masyarakat
Samawa. Jika atap santek terus ditempatkan dalam kedudukan yang penting, maka atap santek tetap akan terjaga kelestariannya.

Pemahaman masyarakat Samawa terhadap satuan lingkungan olat kapung atau dasa adalah kawasan hutan yang belum pernah terganggu atau ditebang untuk diusahakan sebagai kebun atau ladang (Gambar 3). Kawasan hutan ini ditumbuhi oleh berbagai tumbuhan berkayu berukuran besar dan tinggi antara lain rimas (Duabanga moluccana), binong (Tetrameles nudiflora), putat (Barringtonia racemosa), suran (Toona sureni), udu (Litsea accedentoides), doat (Syzygium polyanthum), kesambi (Schleichera oleosa) dan kukini (Actinophora fragrans). 


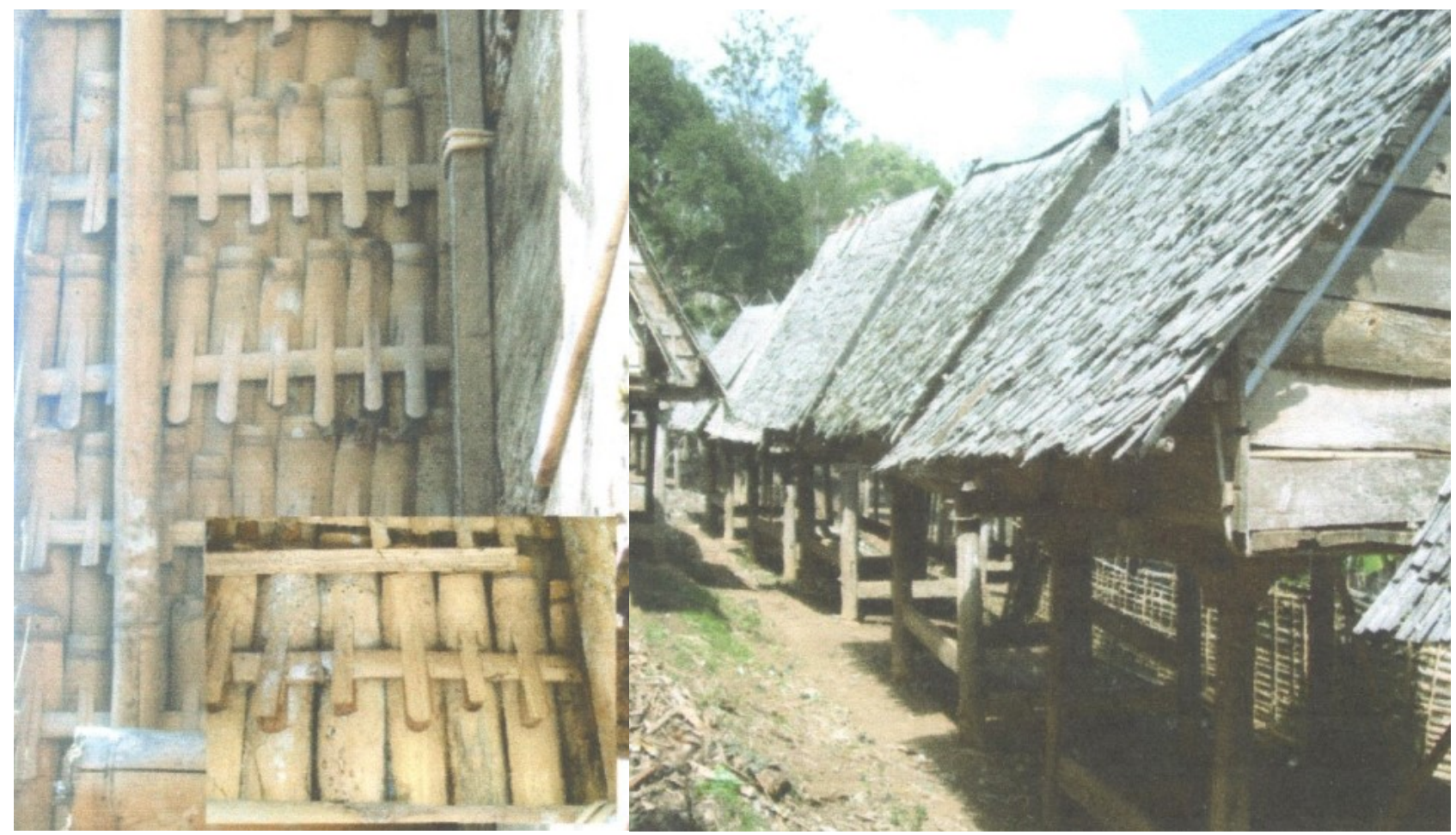

Gambar 2. Santek atau atap bambu dengan inset detil pemasangan (kiri) dan alang atau lumbung padi (kanan) sebagai bangunan asli masyarakat Samawa

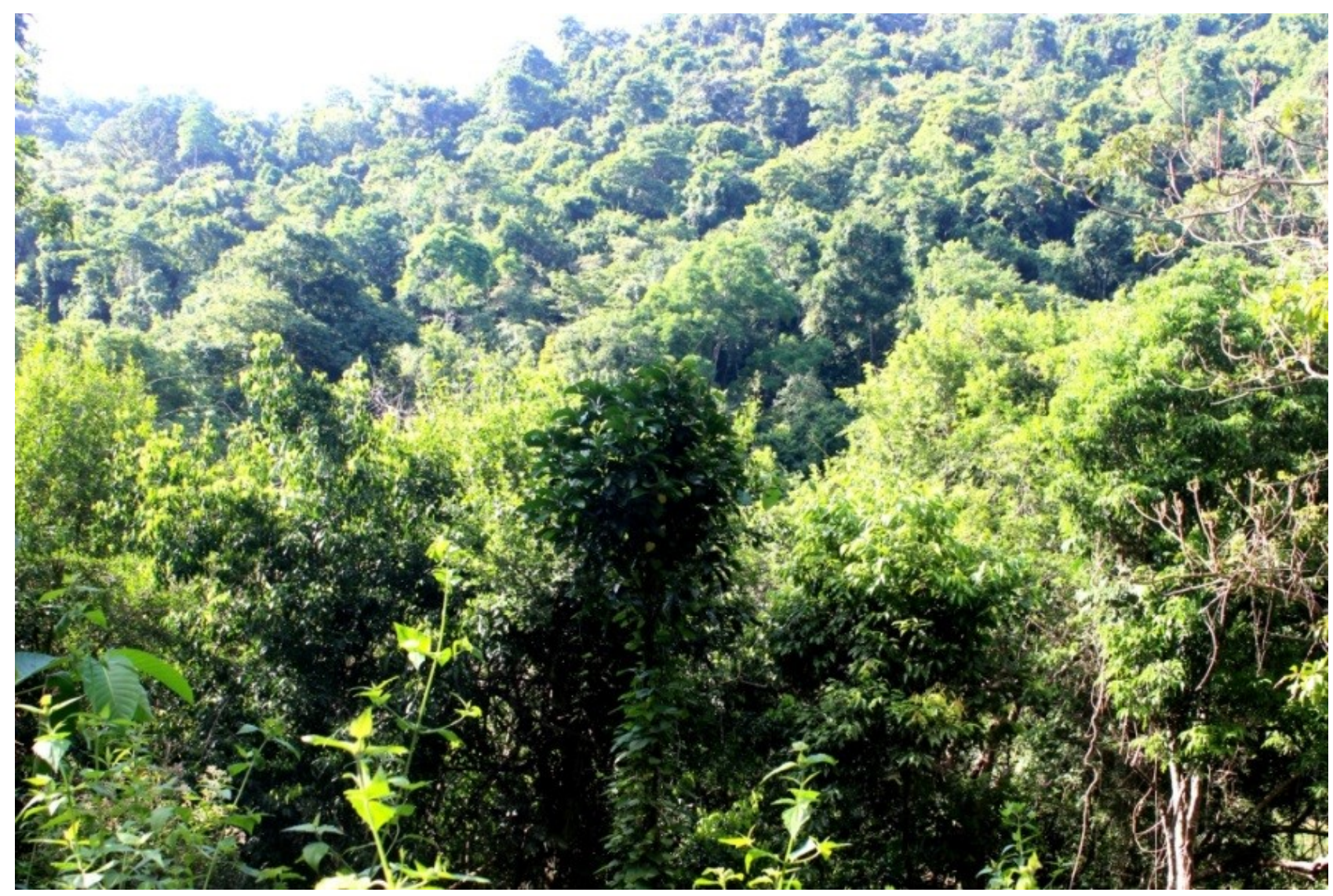

Gambar 3. Hutan Dasa atau kawasan hutan yang belum pernah terganggu atau ditebang untuk diusahakan sebagai kebun atau ladang

Hutan bagi masyarakat Samawa Batudulang memiliki peranan penting, khususnya sebagai habitat lebah madu liar (Apis dorsata). Pengambilan madu alam telah dilakukan sejak lama oleh masyarakat
Samawa Batulanteh terutama masyarakat Batudulang dan Pusu. Rench (1930) melaporkan bahwa kawasan Batulanteh, Batudulang dan Pusu sebagai pusat industri tradisional madu alam Sumbawa. 
Ladang merupakan tempat aktifitas utama masyarakat Samawa Batudulang. Umumnya letak ladang di atas bukit dan berjarak cukup jauh dengan pemukiman (5-10 km). Penanaman padi ladang umumnya $1 \mathrm{x}$ setahun dan dilakukan hanya dalam 3 tahun. Ini menunjukkan bahwa pembukaan lahan baru terus berlangsung untuk memenuhi kebutuhan lahan padi. Varietas pade/padi yang umum ditanam antara lain bali mayang, jereneng kuning, baso, mirah, enggal. Sedangkan lege/ketan/pulut lokal yang umum ditanam pisak, mirah, pandang dan jaran.

Setelah 3 tahun lahan penanaman padi ditinggalkan atau ditanami dengan tanaman palawija atau sayuran. Jenis tanaman palawija yang umum ditanam antara lain baso/jagung (Zea mays), lambui/kedelai hitam (Glycine max), rapo/kacang tanah (Arachis hypogea), kitabang kayu/ ubi kayu (Manihot esculenta), kitabang lonto/ubi jalar (Ipomoea batatas) dan komak (Lablab purpureus); sedangkan tanaman sayuran yang umum ditanam antara lain bayam (Amaranthus hybridus), buncis (Phaseolus vulgaris), lanang/kacang panjang (Vigna unguiculata), ketimun (Cucumis sativus), raras/kangkung (Ipomoea aquatic), terung (para, sepat, bontal, cangi) (Solanum melongena), dan cabai (Capsicum annuum). Tanaman buah-buahan yang umum dibudidayakan antara lain aneka varietas punti/ pisang lokal (kayu, sabah, sang, jadi, lilin, bledang, mirah), pelam/manga (Mangifera indica), lene/semangka (Citrullus lanatus), tuban/sirsak (Annona muricata), paya/pepaya (Carica papaya), durian (Durio zibethinus), avokat (Persea Americana) dan rambutan (Nephelium lappaceum).

Menurut Ruthenberg (1980) dan Dove (1988) strategi penanaman jenis-jenis tersebut di atas dijumpai hampir di seluruh masyarakat lokal di Asia Tenggara. Hal ini dikarenakan penanaman jenis-jenis tersebut pada sistem perladangan tidak memerlukan perawatan intensif dan teknologi yang berat (Brookfield \& Padoch, 1994). Pemahaman masyarakat Samawa Batudulang terhadap satuan lingkungan kebun yaitu adanya lahan yang ditanami tanaman komoditi perdagangan seperti miri/kemiri (Aleurites moluccana) dan kawa/kopi robusta (Coffea canephora). Letak kebun tersebut di sekitar tepi kampung. Penanaman pohon kemiri dilakukan pada tahun 1980-an, sedangkan pohon kopi pada tahun 1990-an. Rata-rata per kepala keluarga (KK) memiliki 200-400 pohon kemiri dan 100-200 pohon kopi. Tahapan proses pengelolaan kemiri disajikan pada Gambar 4.

Mayoritas penduduk di desa Batudulang berasal dari etnis Samawa dan beragama Islam. Mata pencaharian utama mereka adalah bertani kopi robusta, kemiri dan berburu madu hutan dari lebah madu (Apis dorsata). Banyak juga diantara mereka yang berprofesi ganda. Pada mulanya mereka melakukan aktifitas harian menurut tradisi dan keyakinannya. Namun dengan masuknya agama Islam, telah mengalami perubahan. Tradisi atau kebudayaan adalah sesuatu yang dinamis, bergerak dan bukan sesuatu yang statis. Pengetahuan lokal masyarakat Samawa di Batudulang tentang konsep lingkungan dan keragaman tumbuhan berguna tergolong cukup baik. Mereka menjaga keberadaan hutan sebagai bagian kehidupan mereka, terutama dalam kaitannya dengan industri madu lebah liar. Hasil penelitian mencatat 147 jenis tumbuhan dari 63 famili yang dimanfaatkan oleh masyarakat Samawa, yaitu tumbuhan pangan (39 jenis), tumbuhan obat termasuk kosmetik (74 jenis), tumbuhan untuk bahan bangunan dan kerajinan (12 jenis), tumbuhan pakan lebah, sarang lebah, pagar, kayu bakar, bahan ritual sebanyak 22 jenis. Kemiri, kopi robusta dan madu hutan berperan penting dalam perekonomiaan masyarakat Samawa di Batudulang.

Dari hasil penelitian diketahui pemanenan kemiri lokal untuk pertama kali dapat dilakukan jika tanaman telah berumur 5-7 tahun dan menghasilkan 5-10 kg, sedangkan panen maksimal pada umur 2030 tahun dengan hasil 5-100 kg. Panen kemiri umumnya pada bulan Mei s.d. Oktober setiap tahunnya. Pemanenan diambil dari buah yang telah jatuh dari pohonnya, buah yang telah tua, sehingga tidak terjadi kerusakan pada pohon karena pemanenan atau penebangan. Harga jual kemiri lokal Rp3.000,00-Rp5.000,00/kg, sedangkan setelah diproses lebih lanjut (dioven, dibersihkan/dicuci, dipecahkan kulit bijinya, dijemur) dijual dengan harga Rp20.000,00-Rp25.000,00/kg.

Pemanenan kopi dapat dilakukan setelah tanaman kopi berumur 2 tahun, dengan hasil berkisar 2-5 $\mathrm{kg} /$ pohon. Produksi buah kopi maksimal pada umur 5-8 tahun dan menghasilkan 50-70 kg. Pemanenan dilakukan pada bulan Juni s.d. Agustus setiap tahunnya. Harga jual per kg kopi basah Rp3.000,00 buah kopi yang sudah kering Rp20.000,00 sedangkan kopi bubuk setelah melalui beberapa proses antara lain pengeringan di bawah sinar matahari selama 7 hari, dan jika dioven selama 3 hari, kemudian dibersihkan dan ditumbuk halus; dijual dengan harga Rp50.000,00-Rp70.000,00/kg.

Pengetahuan masyarakat Samawa terhadap keragaman tumbuhan berguna untuk kebutuhan sehari-hari antara lain sebagai bahan pangan (karbohidrat, sayuran dan buah-buahan), obat tradisional, bangunan, kayu bakar, pakan lebah madu liar dan lain-lain masih tergolong cukup baik. Tercatat tidak kurang dari 147 jenis tumbuhan berguna yang dimanfaatkan oleh masyarakat Samawa Batudulang (Tabel 1, 2, 3, dan 4). Beberapa tumbuhan yang dimanfaatkan dapat dilihat pada Gambar 5.

Meskipun saat ini di desa Batudulang telah tersedia sarana kesehatan berupa Poliklinik Pedesaan yang ditangani oleh 2 petugas kesehatan, namun peranan sanro/pengobat tradisional dan tawang/dukun beranak masih penting. Dalam prakteknya sanro menangani pengobatan salah urat dengan menggunakan minyak urut yang dibuat pada bulan sura (awal tahun baru umat muslim). 


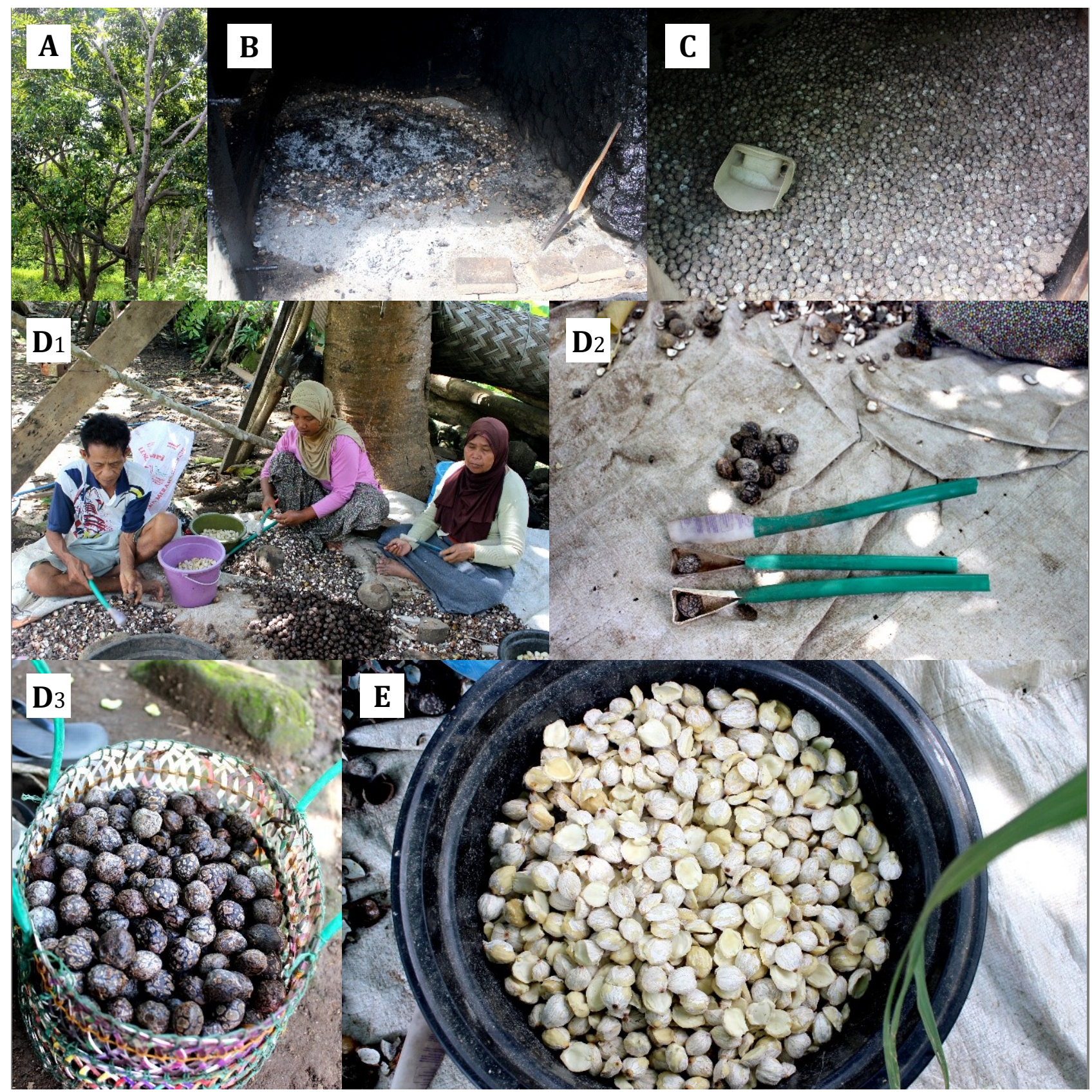

Gambar 4. Tahapan proses pengelolaan kemiri (A) pemanenan, (B) pemanggangan/oven, (C) pembersihan/pencucian, (D1) pengupasan/pemecahan kulit biji, (D2) alat pengupas/pemecah kulit biji, (D3) biji kemiri sebelum dikupas, (E) penjemuran

Minyak urut tersebut berupa santan kelapa yang dimasak dengan ramuan 5 jenis kulit kayu yaitu kanekal (Derris trifoliate), kesaming (Schleichera oleosa), kasokal (Erioglossum rubiginosum), kasene (Capparis sepiaria var. fischeri) dan kasela. Persyaratan kulit kayu yang digunakan dalam ramuan minyak urut harus diambil dari satu naungan pohon dan pemasakannya dikerjakan oleh kaum laki-laki. Sedangkan pembuatannya hanya dilakukan di bulan Sura, karena bulan tersebut dianggap bulan baik sehingga minyak urut yang dihasilkan dapat menyembuhkan penyakit. Perlu dilakukan penelitian lebih lanjut untuk mengetahui lebih dalam tentang khasiat kelima jenis kulit kayu yang digunakan berasal dari pohon yang nama lokalnya berawalan dengan huruf "K" dan harus berasal dari satu naungan pohon.
Peranan dukun beranak di desa Batudulang terutama dalam menangani perawatan paska persalinan. Sementara suku Sasak di Pulau Lombok memiliki pengetahuan perawatan paska persalinan dengan menggunakan 40 jenis simplisia herbal yang dikenal dengan nama "isi kantong" (Rahayu et al., 2002; 2016; Permatasari, 2013). Masyarakat Samawa dengan tujuan yang sama juga mengenal jenis-jenis tumbuhan untuk paska perawatan persalinan. Ramuan perawatan paska persalinan ini bertujuan untuk memperlancar keluarnya darah kotor, mengembalikan kondisi rahim dan vagina, memberi rasa hangat pada tubuh, memperlancar peredaran darah dan memperbanyak keluarnya Air Susu Ibu (ASI) serta mempercepat pemulihan kebugaran tubuh. 


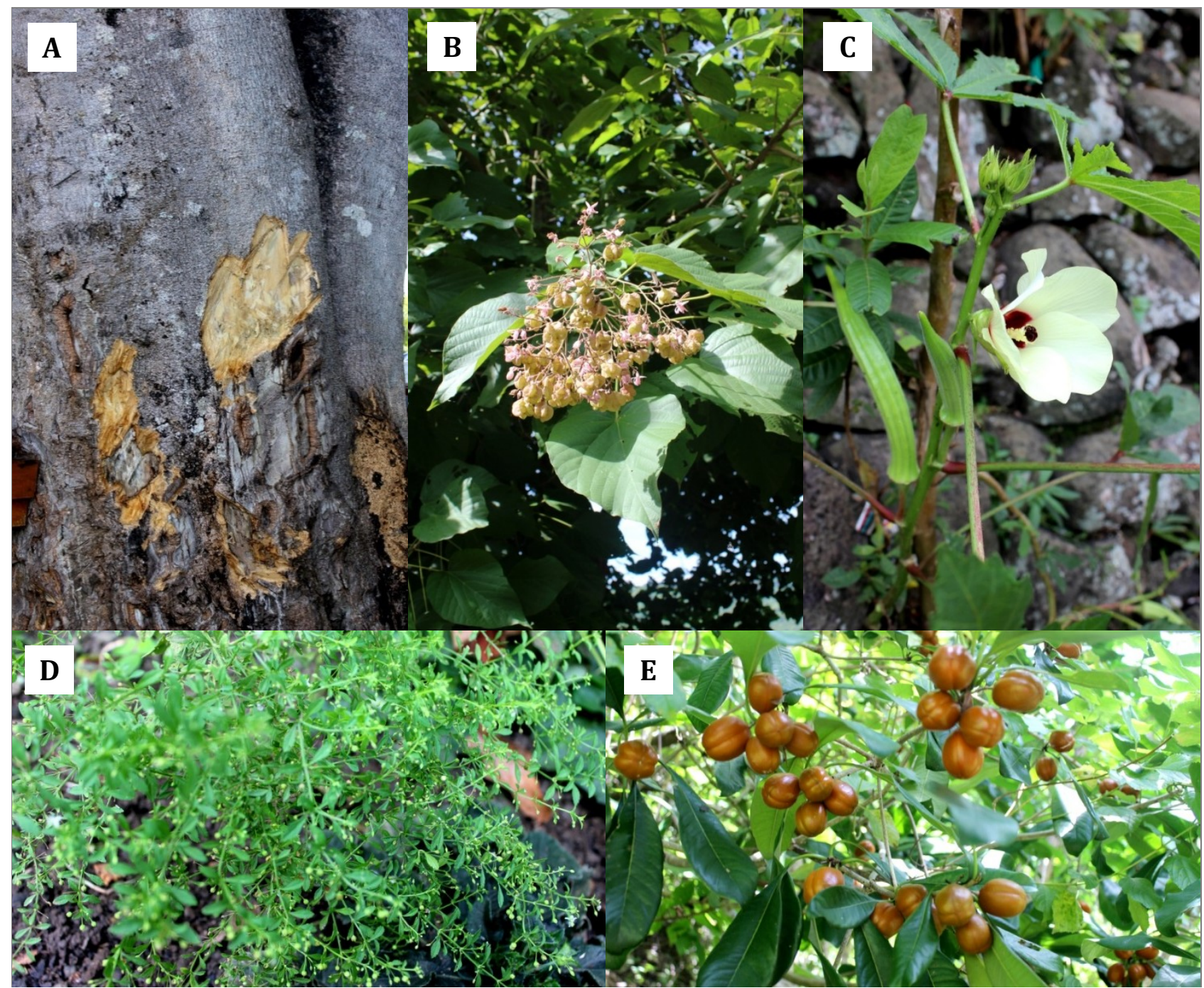

Gambar 5. Beberapa tumbuhan yang dimanfaatkan oleh masyarakat Samawa (A) Alstonia scholaris, (B) Kleinhovia hospita, (C) Abelmoschus esculentus, (D) Glinus oppositifolius, (E) Pittosporum moluccanum

Masyarakat Samawa mengenal dengan baik jenisjenis kayu berkualitas tinggi untuk bahan bangunan dan kayu bakar, namun demikian mereka tidak melakukan penebangan liar untuk memenuhi kebutuhan tersebut. Mereka lebih mengutamakan kelestarian jenis-jenis pohon sebagai habitat lebah madu liar. Saat ini untuk memenuhi kebutuhan bahan bangunan, umumnya diambil dari tanaman budidaya di kebun seperti Cocos nucifera, Aleurites moluccana, Toona sureni, bambu ae, bambu treng, dan bambu doh, sedangkan untuk memenuhi kebutuhan kayu bakar mereka mengambilnya dari patahan-patahan dahan, ranting, atau batang dari tanaman budidaya seperti kelapa, kemiri, mangga atau kopi.

Daun muda ketimis (Protium javanicum), aru (Caesalpinia sp.), dan buah ganista (Limonia acidissima), merupakan sayuran dan buah lokal yang masih dapat dijumpai di pasar-pasar tradisional. Sepanjang pengamatan saat penelitian jenis-jenis tersebut diambil dari hidupan liar dan belum ada usaha pembudidayaan. Darnaedi dan Rodani (1995) melaporkan bahwa kayu ketimis dan aru juga digunakan dalam ramuan perawatan paska persalinan di beberapa desa di kawasan barat daya Sumbawa.
Sedangkan duri dan kulit kayu ganista dilaporkan sebagai bahan ramuan obat tradisional di daratan Asia Tenggara (Jones, 1997).

Hasil wawancara dengan masyarakat setempat diketahui salah satu jenis terong yang dikenal dengan nama lokal terong para digunakan sebagai obat perawatan pasca persalinan. Namun, hasil identifikasi diketahui jenis ini memiliki nama ilmiah yang sama dengan 2 terung lainnya yang dikenal dengan nama lokal talekir, terong sepat dan terong cangi, digunakan sebagai sayuran. Perlu penelitian lebih lanjut antara lain taksonomi dan fitokimia untuk lebih memperjelas status taksonomi dan kandungan senyawa kimianya.

Meskipun di kawasan Batulanteh tidak banyak dijumpai pohon lontar (Borassus flabelliferi), atau jontal, namun masih dijumpai pengrajin anyaman daun lontar antara lain dijadikan untuk tabola/tudung saji makanan, serune/alat musik tiup tradisional, songko/topi, buka bura/wadah simplisia obat pasca persalinan, roko jontal/pembungkus tembakau pisak dan remagan/cetakan majareal/kue tradisional etnis Samawa (Gambar 6). Sedangkan ketak (Lygodium circinnatum) telah dilakukan usaha budidayanya, namun belum dapat dipanen. 


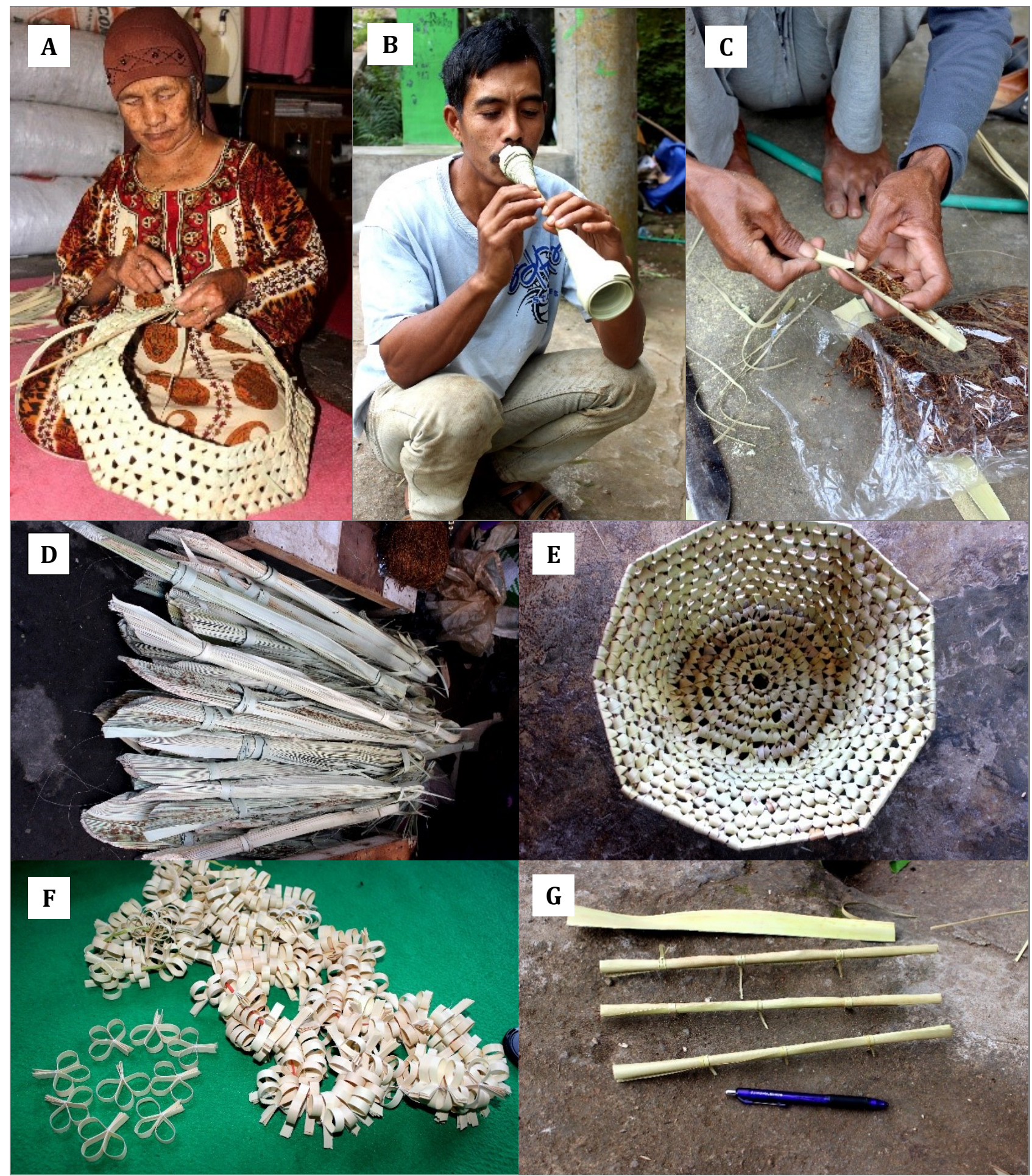

Gambar 6. Beberapa kerajinan anyaman daun lontar (A, E) tabola/tudung saji makanan, (B) serune/alat musik tiup tradisional, (C, D, G) roko jontal/pembungkus tembakau pisak, (F) remagan/cetakan majareal kue tradisional etnis Samawa

Tabel 1. Tumbuhan sebagai sumber pangan di di Desa Batudulang, Sumbawa, NTB

\begin{tabular}{lllll}
\hline No Nama Ilmiah & Nama Lokal & Suku & $\begin{array}{l}\text { Bagian yang } \\
\text { digunakan }\end{array}$ & Kegunaan \\
\hline 1 Abelmoschus esculentus (L.) Moench & jamia & Malvaceae & buah & pangan (sayur) \\
2 Amomum gracile Blume & saram & Zingiberaceae & buah & pangan (buah-buahan) \\
3 Amomum maximum Roxb. & gangsa & Zingiberaceae & buah & pangah-buahan) \\
4 Asystasia nemorum Nees & katepu & Acanthaceae & daun muda & pangan (sayur) \\
5 Celosia argentea L. & lompa & Amaranthaceae & herba & pangan (sayur) \\
6 Champereia manillana (Blume) Merr. & semelu & Opiliaceae & daun muda & pangan (sayur) \\
7 Caesalpinia sp. & aru & Fabaceae & daun muda & campuran sayur atau sepat \\
8 Cinnamomum burmanni (Nees \& T. Nees) & kayu manis & Lauraceae & kulit kayu & penyedap masakam \\
Blume & & & & \\
\hline
\end{tabular}




\begin{tabular}{|c|c|c|c|c|}
\hline No Nama Ilmiah & Nama Lokal & Suku & $\begin{array}{l}\text { Bagian yang } \\
\text { digunakan }\end{array}$ & Kegunaan \\
\hline 9 Claoxylon longifolium (Blume) Endl. ex Hassk. & merutis & Euphorbiaceae & pucuk daun & pangan (sayur) \\
\hline 10 Coriandrum sativum $L$. & ketumbar & Apiaceae & biji & penyedap masakan \\
\hline 11 Curcuma longa L. & kunyit & Zingiberaceae & rimpang & penyedap masakan \\
\hline 12 Dendrocalamus asper (Schoult.) Backer & bambu petung & Poaceae & rebung & pangan (sayur) \\
\hline 13 Dioscorea hispida Dennst. & gadung nyir & Dioscoreaceae & umbi & pangan (sumber karbohidrat) \\
\hline 14 Diospyros lanceifolia Roxb. & ayan & Ebenaceae & buah & pangan (buah-buahan) \\
\hline 15 Elatostema macrophllyum Brongn. & telat & Urticaceae & $\begin{array}{l}\text { batang bagian } \\
\text { dalam, daun }\end{array}$ & pangan (sayur) \\
\hline 16 Elettaria cardamomum (L.) Maton & kapulaga & Zingiberaceae & buah & bumbu \\
\hline $\begin{array}{l}17 \text { Erechtites valerianifolia (Link ex Wolf) Less. ex } \\
\text { DC. }\end{array}$ & ketangkong & Asteraceae & daun muda & pangan (sayur) \\
\hline 18 Ficus sp. & poso & Moraceae & pucuk daun & pangan (sayur) \\
\hline 19 Ficus callosa Willd. & semanpil & Moraceae & buah & pangan (buah-buahan) \\
\hline 20 Ficus racemosa $\mathrm{L}$. & ara & Moraceae & $\begin{array}{l}\text { buah } \\
\text { daun muda }\end{array}$ & $\begin{array}{l}\text { pangan (buah-buahan) } \\
\text { pangan (sayur) }\end{array}$ \\
\hline 21 Glycine max (L.) Merr. & lambui & Fabaceae & biji & pangan (sayur) \\
\hline 22 Gymnema sp. & sesat & Apocynaceae & daun & pangan (sayur) \\
\hline 23 Hibiscus surattensis L. & kapoteng & Malvaceae & & pengganti asam \\
\hline 24 Lablab purpureus (L.) Sweet & komak & Fabaceae & biji & pangan (sayur) \\
\hline 25 Lantana camara $\mathrm{L}$. & sang mamung & Asteraceae & buah & pangan (buah-buahan) \\
\hline 26 Limonia acidissima Groff. & ganista & Rutaceae & buah & pangan (minuman) \\
\hline 27 Maesa perlaria (Lour.) Merr. & greng romong & Myrsinaceae & buah & pangan (buah-buahan) \\
\hline 28 Mangifera indica $\mathrm{L}$. & pelam & Anacardiaceae & buah & pangan (buah-buahan) \\
\hline 29 Melastoma malabathricum L. & biso & Melastomataceae & buah & pangan (buah-buahan) \\
\hline 30 Momordica cf. charantia L. & paria beti & Cucurbitaceae & buah & pangan (sayur) \\
\hline 31 Palaquium obtusifolium Burck & semelu kayu & Sapotaceae & buah & pangan (buah-buahan) \\
\hline 32 Phyllanthus emblica L. & malaka & Phyllanthaceae & buah & pangan (buah-buahan) \\
\hline 33 Pisonia sp. & tulung & Nyctaginaceae & daun & pangan (sayur) \\
\hline 34 Portulaca oleracea L. & ngalir & Portulaceae & daun & pangan (sayur) \\
\hline 35 Protium javanicum Burm.f. & ketimis & Burseraceae & daun muda & pangan (sayur) \\
\hline 36 Rubus rosifolius $\mathrm{Sm}$. & kasisik & Rosaceae & buah & pangan (buah-buahan) \\
\hline 37 Solanum melongena L. & talekir & Solanaceae & buah & pangan (sayur) \\
\hline 38 Solanum melongena L. & $\begin{array}{l}\text { terong sepat, } \\
\text { terong cangi }\end{array}$ & Solanaceae & buah & pangan (sayur) \\
\hline 39 Solanum torvum Sw. & $\begin{array}{l}\text { terong renge, } \\
\text { terong bontal }\end{array}$ & Solanaceae & buah & pangan (sayur) \\
\hline 40 Syzygium aromaticum (L.) Merr. \& L.M. Perry & cengkeh & Myrtaceae & biji & $\begin{array}{l}\text { komoditi perdagangan, } \\
\text { pengharum masakan }\end{array}$ \\
\hline 41 Syzygium cumini (L.) Skeels & juwet & Myrtaceae & buah & pangan (buah-buahan) \\
\hline
\end{tabular}

Tabel 2. Tumbuhan sebagai sumber obat dan kosmetik di di Desa Batudulang, Sumbawa, NTB

\begin{tabular}{|c|c|c|c|c|}
\hline No Nama Ilmiah & Nama Lokal & Suku & $\begin{array}{l}\text { Bagian yang } \\
\text { digunakan }\end{array}$ & Kegunaan \\
\hline 1 Aganosma wallichii G.Don & jeliti & Apocynaceae & daun & obat demam \\
\hline 2 Aleurites moluccanus (L.) Willd. & miri & Euphorbiaceae & $\begin{array}{l}\text { daun yang telah } \\
\text { kuning }\end{array}$ & kosmetika (pemutih wajah), \\
\hline 3 Aloe vera (L.) Burm. f. & sekir baya & Xanthorrhoeaceae & daun & $\begin{array}{l}\text { perangsang ASI, pengganti } \\
\text { sampo }\end{array}$ \\
\hline 4 Alstonia scholaris (L.) R. Br. & lita & Apocynaceae & kulit kayu & $\begin{array}{l}\text { obat panas, obat malaria, } \\
\text { perawatan pasca persalinan }\end{array}$ \\
\hline 5 Alyxia pilosa Miq. & kayu batu & Apocynaceae & kulit kayu & perawatan pasca persalinan \\
\hline 6 Annona muricata L. & tuban & Annonaceae & daun & pembasmi kutu rambut \\
\hline 7 Areca catechu L. & pinang & Arecaceae & $\begin{array}{l}\text { buah } \\
\text { akar }\end{array}$ & $\begin{array}{l}\text { sirih pinang } \\
\text { obat kuat laki-laki }\end{array}$ \\
\hline 8 Averrhoa bilimbi L. & binang & Oxalidaceae & daun & ramuan pasca persalinan \\
\hline 9 Bischofia javanica Blume & lintung & Euphorbiaceae & kulit kayu & ramuan pasca persalinan \\
\hline 10 Blumea balsamifera (L.) DC. & kasemung & Asteraceae & daun & perawatan pasca persalinan \\
\hline 11 Caesalpinia bonduc (L.) Roxb. & marugi & Fabaceae & biji & $\begin{array}{l}\text { obat (pasca persalinan, } \\
\text { diabetes) }\end{array}$ \\
\hline 12 Caesalpinia sappan L. & sepang & Fabaceae & kulit kayu & penambah darah \\
\hline 13 Calotropis gigantea (L.) Dryand. & mariga & Apocynaceae & getah & obat (sakit gigi) \\
\hline 14 Canna hybrida Hort. & bunga kuku & Cannaceae & bunga & kosmetika (pewarna kuku) \\
\hline 15 Capparis sepiaria var. fischeri (Pax) DeWolf & kasane & Capparidaceae & kulit batang & ramuan untuk minyak urut \\
\hline 16 Centella asiatica (L.) Urb. & bebele & Apiaceae & herba & memperlancar air seni \\
\hline 17 Cheilocostus speciosus (J.Koenig) C.D.Specht & & Costaceae & daun & obat kemabas atau stroke ringan \\
\hline 18 Chromolaena odorata (L.) R.M.King \& H.Rob. & sentalu & Asteraceae & daun & obat mag \\
\hline $\begin{array}{l}19 \text { Cinnamomum burmanni (Nees \& T. Nees) } \\
\text { Blume }\end{array}$ & kayu manis & Lauraceae & biji & ramuan pasca persalinan \\
\hline 20 Cinnamomum iners Reinw. ex Reinw. & kayu lawang & Lauraceae & kulit kayu & obat sakit kepala \\
\hline 21 Citrus aurantifolia (Christm.) Swingle & limo lawas & Rutaceae & $\begin{array}{l}\text { akar } \\
\text { buah }\end{array}$ & $\begin{array}{l}\text { obat pegal linu } \\
\text { penghilang bau amis ikan }\end{array}$ \\
\hline 22 Citrus hystrix DC. & lawar & Rutaceae & air buah & agar mata terang \\
\hline
\end{tabular}




\begin{tabular}{|c|c|c|c|c|}
\hline No Nama Ilmiah & Nama Lokal & Suku & $\begin{array}{l}\text { Bagian yang } \\
\text { digunakan }\end{array}$ & Kegunaan \\
\hline 23 Citrus sp. & jeruk sumba & Rutaceae & buah & pengganti sampo (anti ketombe) \\
\hline 24 Cocos nucifera L. & nyir & Arecaceae & akar & obat kuat laki-laki \\
\hline 25 Cordia myxa L. & nunang & Boraginaceae & $\begin{array}{l}\text { buah/getah } \\
\text { akar }\end{array}$ & $\begin{array}{l}\text { pengganti lem } \\
\text { obat sakit kuning }\end{array}$ \\
\hline 26 Coriandrum sativum $\mathrm{L}$. & ketumbar & Apiaceae & biji & ramuan pasca persalinan \\
\hline 27 Curcuma longa $\mathrm{L}$. & kunyit & Zingiberaceae & rimpang & obat balita agar sehat \\
\hline 28 Derris trifoliata Lour. & kanekal & Fabaceae & kulit batang & ramuan untuk minyak urut \\
\hline 29 Elettaria cardamomum (L.) Maton & kapulaga & Zingiberaceae & buah & ramuan pasca persalinan \\
\hline 30 Erioglossum rubiginosum (Roxb.) Blume & kasoka & Sapindaceae & kulit batang & ramuan untuk minyak urut \\
\hline 31 Euphorbia hirta L. & sarat kuku & Euphorbiaceae & getah & kosmetika (agar kuku kuat) \\
\hline 32 Euphorbia thymifolia L. & mata bisa & Euphorbiaceae & herba & antimual untuk wanita hamil \\
\hline 33 Ficus fistulosa Reinw. ex Blume & suwir & Moraceae & kulit kayu & obat disentri \\
\hline 34 Ficuss agittata Vahl & ara munung & Moraceae & batang & obat sakit pinggang \\
\hline 35 Glinus oppositifolius (L.) Aug.DC. & jempait & Molluginaceae & daun & obat (malaria) \\
\hline 36 Glochidion $s p$ & kayu ceremai & Euphorbiaceae & kulit kayu & ramuan pasca persalinan \\
\hline 37 Graptophyllum pictum (L.) Griff. & sate ati & Acanthaceae & daun & $\begin{array}{l}\text { obat memperlancar urine, } \\
\text { penurun panas }\end{array}$ \\
\hline & & & akar & obat penambah nafsu makan \\
\hline 38 Grewia multiflora Juss. & kayu modeng & Tiliaceae & kulit kayu & obat disentri \\
\hline 39 Gymnema lactiferum (L.) R.Br. ex Schult. & $\begin{array}{l}\text { katemung } \\
\text { buntit }\end{array}$ & Apocynaceae & akar & $\begin{array}{l}\text { penambah nafsu makan, } \\
\text { obat pegal }\end{array}$ \\
\hline 40 Hydrocotyle sibthorpioides Lam. & bebele & Apiaceae & daun & $\begin{array}{l}\text { obat sakit kepala, keputihan, bau } \\
\text { mulut, pegal-pegal }\end{array}$ \\
\hline 41 Jatropha curcas L. & jarak & Euphorbiaceae & daun & pemutih wajah \\
\hline 42 Lawsonia inermis $L$. & pancar & Lythraceae & daun & kosmetika (pewarna kuku) \\
\hline 43 Litsea tomentosa Blume & kayu ela & Lauraceae & kulit kayu & ramuan pasca persalinan \\
\hline 44 Maclura cochinchinensis (Lour.) Corner & galiaga & Moraceae & kulit kayu & pewarna kuning \\
\hline 45 Mangifera indica $\mathrm{L}$. & pelam & Anacardiaceae & kulit kayu & lulur wajah \\
\hline & & & ranting, batang & kayu bakar \\
\hline 46 Marsilea crenataC.Presl & semanggi & Marsileaceae & herba & $\begin{array}{l}\text { pengganti shampo (anti } \\
\text { ketombe) }\end{array}$ \\
\hline 47 Melastoma malabathricum L. & biso & Melastomataceae & rangkaian bunga & obat campak \\
\hline 48 Melia azedarach L. & mindi & Meliaceae & daun & obat diabetes \\
\hline 49 Momordica cf. charantia L. & paria beti & Cucurbitaceae & daun & obat malaria \\
\hline 50 Moringa oleifera Lam. & ketujur & Moringaceae & daun dan bunga & $\begin{array}{l}\text { sayur untuk perawatan pasca } \\
\text { persalinan }\end{array}$ \\
\hline 51 Oroxylum indicum (L.) Kurz & bakam bote & Bignoniaceae & $\begin{array}{l}\text { kulit kayu dan } \\
\text { daun }\end{array}$ & penurun panas \\
\hline 52 Pandanus amaryllifolius Roxb. & pandan wangi & Pandanaceae & daun & $\begin{array}{l}\text { pewangi makanan, campuran air } \\
\text { memandikan jenazah }\end{array}$ \\
\hline 53 Pandanus faviger Backer & pandan layun & Pandanaceae & akar gantung & obat kuat laki-laki \\
\hline 54 Peperomia pellucida (L.) Kunth & kedesan & Piperaceae & daun & $\begin{array}{l}\text { obat mag, obat pegal, penyubur } \\
\text { kandungan }\end{array}$ \\
\hline 55 Phyllanthus acidus (L.) Skeels & ceremai & Phyllanthaceae & daun & ramuan pasca persalinan \\
\hline 56 Phyllanthus emblica L. & malaka & Phyllanthaceae & buah & obat sakit mata \\
\hline 57 Phyllanthus urinaria L. & sirkajang & Phyllanthaceae & herba & obat gatal-gatal, hipertensi \\
\hline 58 Piper betle L. & eta & Piperaceae & daun & $\begin{array}{l}\text { ramuan pasca persalinan, obat } \\
\text { tetes mata }\end{array}$ \\
\hline 59 Piper nigrum L. & sang & Piperaceae & biji & ramuan pasca persalinan \\
\hline 60 Piper retrofractum Vahl & cabe ulet & Piperaceae & buah & ramuan pasca persalinan \\
\hline 61 Piper sarmentosum Roxb. & kaduk & Piperaceae & daun & $\begin{array}{l}\text { obat sesak nafas, penurun } \\
\text { demam }\end{array}$ \\
\hline 62 Piper umbellatum L. & oma & Piperaceae & buah & obat cacing \\
\hline $\begin{array}{l}63 \text { Pisonia umbellifera (J.R. Forst. \& G. Forst.) } \\
\text { Seem. }\end{array}$ & kayu kalong & Nyctaginaceae & kulit kayu & $\begin{array}{l}\text { memperlancar peredaran darah } \\
\text { balita }\end{array}$ \\
\hline 64 Pittosporum moluccanum Miq. & malam foto & Pittosporaceae & buah & racun \\
\hline 65 Plectranthus amboinicus (Lour.) Spreng. & poko & Lamiaceae & daun & mencegah payudara bengkak \\
\hline 66 Portulaca oleracea L. & ngalir & Portulaceae & daun & $\begin{array}{l}\text { untuk mempercepat proses } \\
\text { persalinan }\end{array}$ \\
\hline 67 Rhaphidophora korthalsii Schott & melung & Araceae & $\begin{array}{l}\text { batang } \\
\text { pucuk daun }\end{array}$ & $\begin{array}{l}\text { obat luka } \\
\text { pengganti sampo }\end{array}$ \\
\hline 68 Sapindus rarak DC. & suat & Sapindaceae & buah & $\begin{array}{l}\text { pengganti sabun pencuci } \\
\text { pakaian }\end{array}$ \\
\hline 69 Schleichera oleosa (Lour.) Merr. & kasani & Sapindaceae & kulit batang & ramuan untuk minyak urut \\
\hline 70 Sesamum indicum L. & $\begin{array}{l}\text { lengga pisak, } 1 . \\
\text { jaran }\end{array}$ & Pedaliaceae & biji & $\begin{array}{l}\text { rempah untuk masakan daging, } \\
\text { rempah sayuran }\end{array}$ \\
\hline 71 Sida acuta Burm.f. & salaguri & Malvaceae & akar & obat rematik. \\
\hline 72 Sida rhombifolia L. & $\begin{array}{l}\text { selagori } \\
\text { nampok }\end{array}$ & Malvaceae & akar & obat asam urat \\
\hline 73 Solanum melongena L. & terong para & Solanaceae & buah & perawatan pasca persalinan \\
\hline 74 Stachytarpheta jamaicensis (L.) Vahl & gegaret hejo & Verbenaceae & akar & penurun panas \\
\hline 75 Stephania japonica (Thunb.) Miers & sekopal ae & Menispermaceae & daun & obat luka bakar \\
\hline 76 Syzygium aromaticum (L.) Merr. \& L.M. Perry & cengkeh & Myrtaceae & biji & ramuan pasca persalinan \\
\hline
\end{tabular}




\begin{tabular}{|c|c|c|c|c|}
\hline No Nama Ilmiah & Nama Lokal & Suku & $\begin{array}{l}\text { Bagian yang } \\
\text { digunakan }\end{array}$ & Kegunaan \\
\hline 77 Talinum paniculatum (Jacq.) Gaertn. & ginseng & Talinaceae & $\begin{array}{l}\text { akar } \\
\text { daun }\end{array}$ & $\begin{array}{l}\text { obat rematik, penyubur rambut } \\
\text { sayur untuk mempercepat } \\
\text { persalinan }\end{array}$ \\
\hline 78 Tetrameles nudiflora $\mathrm{R} . \mathrm{Br}$. & binong & Tetramelaceae & kulit kayu & pewarna alami (hitam) \\
\hline 79 Toddalia sp. & kayu berabuk & Rutaceae & daun & obat pegal linu \\
\hline 80 Trichosanthes sp. & $\begin{array}{l}\text { temuruk } \\
\text { gamang }\end{array}$ & Cucurbitaceae & biji & obat demam \\
\hline 81 Virola surinamensis (Roi. ex Rottb.) Warb. & pala olat & Myristicaceae & kulit kayu & $\begin{array}{l}\text { penurun panas, menjaga } \\
\text { kebugaran }\end{array}$ \\
\hline 82 Zingiber montamum (J.Koenig) Link ex A. Didr. & bangle & Zingiberaceae & rimpang & obat balita \\
\hline 83 Zingiber officinale Roscoe & je & Zingiberaceae & rimpang & ramuan pasca persalinan \\
\hline
\end{tabular}

Tabel 3. Tumbuhan untuk bahan bangunan dan kerajinan di Desa Batudulang, Sumbawa, NTB

\begin{tabular}{|c|c|c|c|c|}
\hline No Nama Ilmiah & Nama Lokal & Suku & $\begin{array}{l}\text { Bagian yang } \\
\text { digunakan }\end{array}$ & Kegunaan \\
\hline 1 Aleurites moluccanus (L.) Willd. & miri & Euphorbiaceae & batang & bahan bangunan \\
\hline 2 Bambusa vulgaris Schrad. & bambu tutul & Poaceae & batang & bahan kerajinan anyaman \\
\hline 3 Borassus flabellifer $\mathrm{L}$. & jontal & Arecaceae & $\begin{array}{l}\text { daun } \\
\text { "ae jontal" nira } \\
\text { pohon }\end{array}$ & $\begin{array}{l}\text { bahan kerajinan anyaman } \\
\text { bahan baku gula } \\
\text { tanaman hias }\end{array}$ \\
\hline 4 Clematis sp. & lonto kasupit & Ranunculaceae & batang & pengganti tali \\
\hline 5 Cocos nucifera $\mathrm{L}$. & nyir & Arecaceae & batang & bahan bangunan \\
\hline 6 Cyathea contaminans (Wall. ex Hook.) Copel & pakis treng & Cyatheaceae & batang & bahan kerajinan \\
\hline 7 Dipterocarpus retusus Blume & prek mayung & Dipterocarpaceae & batang & bahan bangunan \\
\hline 8 Duabanga moluccana Blume & kayu rimas & Lytraceae & kayu & bahan bangunan \\
\hline 9 Gossypium arboreum L. & kapas mayung & Malvaceae & batang & bahan bangunan \\
\hline 10 Kleinhovia hospita L. & blora & Malvaceae & kulit kayu & tali temali \\
\hline 11 Moringa oleifera Lam. & ketujur & Moringaceae & getah & lem kayu \\
\hline 12 Palaquium obtusifolium Burck & semelu kayu & Sapotaceae & kayu & peralatan rumah tangga \\
\hline 13 Pandanus tectorius Parkinson ex Du Roi & pandang & Pandanaceae & daun & bahan anyaman \\
\hline 14 Tetrastigma papillosum Planch. & ulir & Vitaceae & batang & bahan pengikat \\
\hline \multirow[t]{6}{*}{15 Toona sureni (Blume) Merr. } & suran & Meliaceae & kayu & bahan bangunan \\
\hline & bambu ae & Poaceae & batang & bahan atap rumah/santek \\
\hline & bambu treng & Poaceae & batang & bahan atap rumah/santek \\
\hline & bambu buluh & Poaceae & batang & bahan alat musik serune, pancing \\
\hline & bambu doh & Poaceae & batang & dinding rumah \\
\hline & bambu beta & Poaceae & batang & deneng atau alu \\
\hline 16 Sida rhombifolia L. & $\begin{array}{l}\text { selagori } \\
\text { nampok }\end{array}$ & Malvaceae & batang & bahan sapu \\
\hline
\end{tabular}

Tabel 4. Tumbuhan untuk tumbuhan pakan lebah, sarang lebah, pagar, kayu bakar, bahan ritual dan komoditi perdagangan di Desa Batudulang, Sumbawa, NTB

\begin{tabular}{|c|c|c|c|c|}
\hline No Nama Ilmiah & Nama Lokal & Suku & $\begin{array}{l}\text { Bagian yang } \\
\text { digunakan }\end{array}$ & Kegunaan \\
\hline 1 Agave sisalana Pierre & panan ring & Agavaceae & daun & penangkal setan \\
\hline 2 Aleurites moluccanus (L.) Willd. & miri & Euphorbiaceae & biji & komoditi perdagangan \\
\hline 3 Artemisia scoparia Waldst. \& Kitam. & bunga angin & Asteraceae & pucuk daun & sebagai sarang burung \\
\hline $\begin{array}{l}4 \text { Austroeupatorium inulaefolium (Kunth) R.M. } \\
\text { King \& H. Rob }\end{array}$ & santolo & Asteraceae & bunga & pakan lebah \\
\hline 5 Bambusa blumeana Schult.f. & bambu duri & Poaceae & batang & pagar \\
\hline 6 Cocos nucifera $\mathrm{L}$. & nyir & Arecaceae & $\begin{array}{l}\text { bunga } \\
\text { tangkai daun }\end{array}$ & $\begin{array}{l}\text { pakan lebah } \\
\text { kayu bakar }\end{array}$ \\
\hline 7 Coffea canephora Pierre ex A. Froehner & kopi & Rubiaceae & $\begin{array}{l}\text { buah } \\
\text { bunga }\end{array}$ & $\begin{array}{l}\text { komoditi perdaganagan } \\
\text { pakan lebah }\end{array}$ \\
\hline 8 Crescentia cujete $\mathrm{L}$. & maja & Bignoniaceae & $\begin{array}{l}\text { pohon } \\
\text { bunga } \\
\text { pohon }\end{array}$ & $\begin{array}{l}\text { tanaman pagar } \\
\text { pakan lebah } \\
\text { sarang/habitat lebah }\end{array}$ \\
\hline $\begin{array}{l}9 \text { Dipterocarpus retusus Blume } \\
10 \text { Dolichandrone } \mathrm{sp}\end{array}$ & $\begin{array}{l}\text { prek mayung } \\
\text { bunga kuta }\end{array}$ & $\begin{array}{l}\text { Dipterocarpaceae } \\
\text { Bignoniaceae }\end{array}$ & pohon & $\begin{array}{l}\text { sarang/habitat lebah } \\
\text { tanaman hias }\end{array}$ \\
\hline 11 Dysoxylum sp. & kayu tahi & Meliaceae & $\begin{array}{l}\text { buah } \\
\text { kayu }\end{array}$ & $\begin{array}{l}\text { pakan monyet } \\
\text { kayu bakar }\end{array}$ \\
\hline 12 Duabanga moluccana Blume & kayu rimas & Lytraceae & $\begin{array}{l}\text { bunga } \\
\text { pohon }\end{array}$ & $\begin{array}{l}\text { pakan lebah } \\
\text { sarang/habitat lebah }\end{array}$ \\
\hline 13 Erythrina subumbrans (Hassk.) Merr. & rupe & Fabaceae & $\begin{array}{l}\text { pohon } \\
\text { bunga }\end{array}$ & $\begin{array}{l}\text { tanaman pagar, pelindung kopi } \\
\text { pakan lebah }\end{array}$ \\
\hline 14 Gossypium arboreum L. & kapas mayung & Malvaceae & $\begin{array}{l}\text { batang } \\
\text { serat kulit buah }\end{array}$ & $\begin{array}{l}\text { bahan bangunan, kayu bakar } \\
\text { kapas }\end{array}$ \\
\hline 15 Etlingera heyneana (Valeton) R.M. Smith & goal & Zingiberaceae & $\begin{array}{l}\text { Bunga } \\
\text { buah }\end{array}$ & $\begin{array}{l}\text { pakan lebah } \\
\text { memandikan jenasah }\end{array}$ \\
\hline 16 Exocarpos longifolius (L.) Endl. & kayu sulaiman & Santalaceae & akar dan batang & magik (penyubur padi) \\
\hline
\end{tabular}




\begin{tabular}{|c|c|c|c|c|}
\hline No Nama Ilmiah & Nama Lokal & Suku & $\begin{array}{l}\text { Bagian yang } \\
\text { digunakan }\end{array}$ & Kegunaan \\
\hline 17 Flemingia strobilifera (L.) W.T. Aiton & sarenggang & Fabaceae & bunga & pengganti kapuk \\
\hline 18 Gossypium arboreum L. & kapas mayung & Malvaceae & pohon & tanaman pagar \\
\hline 19 Leea indica L. & kayu rante & Vitaceae & daun dan buah & magik (penyubur padi) \\
\hline 20 Limonia acidissima Groff. & ganista & Rutaceae & batang & kayu bakar \\
\hline 21 Litsea accedentoides Koord. \& Valeton & udu & Lauraceae & bunga & pakan lebah \\
\hline 22 Melochia umbellata (Houtt.) Stapf & lentunu & Malvaceae & $\begin{array}{l}\text { pohon } \\
\text { batang }\end{array}$ & $\begin{array}{l}\text { sarang/habitat lebah } \\
\text { kayu bakar }\end{array}$ \\
\hline 23 Melocope sp. & mpang & Rutaceae & bunga & pakan lebah \\
\hline 24 Mimosa pudica L. & sarat & Fabaceae & bunga & pakan lebah \\
\hline 25 Nicotiana tabaccum L. & mako & Solanaceae & daun & rokok \\
\hline 26 Planchonia valida (Blume) Blume & belinat & Lecythidaceae & $\begin{array}{l}\text { bunga } \\
\text { pohon }\end{array}$ & $\begin{array}{l}\text { pakan lebah } \\
\text { sarang/habitat lebah }\end{array}$ \\
\hline 27 Schoutenia ovata Korth. & kukim & Malvaceae & $\begin{array}{l}\text { bunga } \\
\text { pohon }\end{array}$ & $\begin{array}{l}\text { pakan lebah } \\
\text { sarang/habitat lebah }\end{array}$ \\
\hline 28 Spondias sp. & kuhinu & Anacardiaceae & $\begin{array}{l}\text { bunga } \\
\text { pohon }\end{array}$ & $\begin{array}{l}\text { pakan lebah } \\
\text { sarang/habitat lebah }\end{array}$ \\
\hline 29 Syzygium polyanthum (Wighat) Walp & doat & Myrtaceae & $\begin{array}{l}\text { bunga } \\
\text { pohon }\end{array}$ & $\begin{array}{l}\text { pakan lebah } \\
\text { sarang/habitat lebah }\end{array}$ \\
\hline 30 Tetrameles nudiflora $\mathrm{R} . \mathrm{Br}$. & binong & Tetramelaceae & pohon & sarang/habitat lebah \\
\hline
\end{tabular}

\section{KES I M P U L A N}

Pengetahuan lokal masyarakat Samawa di Batudulang tentang konsep lingkungan dan keragaman tumbuhan berguna tergolong cukup baik. Mereka menjaga keberadaan hutan sebagai bagian kehidupan mereka, terutama dalam kaitannya dengan industri madu lebah liar. Hasil penelitian mencatat 147 jenis tumbuhan dari 63 famili yang dimanfaatkan oleh masyarakat Samawa, yaitu tumbuhan pangan (39 jenis), tumbuhan obat termasuk kosmetik (74 jenis), tumbuhan untuk bahan bangunan dan kerajinan (12 jenis), tumbuhan pakan lebah, sarang lebah, pagar, kayu bakar, bahan ritual sebanyak 22 jenis. Kemiri, kopi robusta dan madu hutan berperan penting dalam perekonomiaan masyarakat Samawa di Batudulang.

\section{DAFT AR REFERENSI}

Brookfield HD, Padoch C. 1994. Apreciating agrodiversity: A look at the dynamism and diversity of Indegineous Farming Practise. Environment. 36 (5):6-11.

Cunningham AB. 2001. Applied ethnobotany: people, wild plant use \& conservation. London: Earthscan Publication.

Darnaedi SY, Rodani. 1995. Kearifan budaya dalam tradisi pengobatan orang Sumbawa Barat Daya, Nusa Tenggara Barat. Prosiding Seminar dan Lokakarya Nasional Etnobotani II. Buku I. Puslitbang Biologi-LIPI, Fakultas Biologi Universitas Gadjah Mada dan Ikatan Pustakawan Indonesia. p. 29-38.

Dove MR. 1988. Sistem perladangan di Indonesia: suatu studi dari Kalimantan Barat. Yogyakarta: Gadjah Mada University Press.
Fox JJ. 1993. Comperative perpective on Austronesia houses: An introductory essay. In: Fox JJ (ed.) Inside Austronesia houses: perspective on domestic design for living. Canberra: Australian National University. p. 1-10

Hoang SV, Baas P, Kebler JA. 2008. Use and conservation of plant species in National Park: A case study of Ben In, Vietnam. Economic Botany. 62(4): 574-593.

Jones DT. 1997. Limonia acidissima L. In: Verheij EWM \& RE Coronel (Eds.). Buah-buahan yang dapat dimakan. PROSEA Sumber Daya Nabati Asia Tenggara 2. Jakarta: PT Gramedia Pustaka Utama..

Kostermans AJGH. 1963. Notes on the vegetation of West Sumbawa (Indonesia). Symposium on the Ecology of Reserved Humid Tropical Vegetation; Kuching.

Permatasari I. 2013. Etnobotani tumbuhan bahan dasar minyak Sumbawa di Kabupaten Sumbawa Besar Provinsi Nusa Tenggara Barat (NTB) [thesis]. Universitas Islam Negeri Maulana Malik Ibrahim.

Rahayu M, Rugayah, Praptiwi, Hamzah. 2002. Keragaman pemanfaatan tumbuhan obat oleh masyarakat suku Sasak Di Taman Nasional Gunung Rinjani, Lombok-NTB. Prosiding Simposium Nasional II Tumbuhan Obat dan Aromatik. KEHATI, LIPI, APINMAP, UNESCO dan JICA. Bogor, 8-9 Agustus 2001. Hal: $116-123$.

Rahayu M, Rustiami H, Rugayah. 2016. Ethnobotanical study of Sasak Ethnic, East Lombok, West Nusa Tenggara. Journal of Tropical Biology and Conservation. 13: 85-99.

Rench B. 1930. Eine biologische reise nach den Kleinen Sunda-Insel. Berlin: Gebruder Borntraeger.

Ruthenberg H. 1980. Farming system in the tropics. Oxford: Clarendon Press.

Telle K. 2007. Entangled biographies: rebuilding a Sasak house. Journal of Anthropology. 72 (2): 195-218. 